WARSZTATY Z GEOGRAFII TURYZMU

ISBN 978-83-7969-138-8 $\quad$ s. 71-88

http://dx.doi.org/10.18778/7969-138-8.06

Marta WAWRZYNIAK

Uniwersytet Łódzki

\title{
ORGANIZACJA PRZESTRZENI TURYSTYCZNEJ W MIEŚCIE
}

\section{Wstęp}

Pojęcie przestrzeni turystycznej jest definiowane i precyzowane $\mathrm{w}$ literaturze przedmiotu przez wielu autorów. Zapoznając się z nią można zauważyć, że określenie organizacji przestrzeni turystycznej pojawia się niezwykle rzadko, bez podania konkretnej definicji. Celem niniejszego opracowania jest próba zdefiniowania tego pojęcia oraz wyjaśnienia tego, jakie efekty niesie ze sobą zorganizowanie przestrzeni turystycznej.

\section{Koncepcje organizacji}

Pojęcie „organizacja” pochodzi od łacińskiego słowa organum oraz greckiego organom, które znaczą „narzędzie”. Potocznie to słowo oznacza ład, porządek i logikę.

Ogólną definicję podaje T. KOTARBIŃSKI (1965): „Organizacja jest pewnym rodzajem całości ze względu na stosunek do niej jej własnych elementów, a mianowicie taką całością, której wszystkie składniki współprzyczyniają się do powodzenia całości."

Określenie „organizacja”, jak zauważył J. ZIELENIEWSKI (1979), ma trzy znaczenia, które użyte w zależności od kontekstu mogą oznaczać co innego. 
Pierwszym z nich jest znaczenie atrybutowe, które inaczej można określić jako przymiotnikowe, czyli takie, które opisuje cechy oraz rodzaj stosunków i relacji elementów pewnej całości, decydujących o powodzeniu tej całości. Przykładem użycia znaczenia atrybutowego może być zdanie: „W naszej firmie jest dobra organizacja".

Drugie znaczenie organizacji ma charakter rzeczowy, jest synonimem instytucji lub pewnej całości złożonej z elementów czy zadań. Przykładem niech będzie stwierdzenie: „Stowarzyszenie X jest organizacją turystyczną".

Trzecie znaczenie organizacji dotyczy czynności, jest pewnym działaniem, które ma pozwolić na powodzenie całości. Tu zamiennie można użyć określenia „zorganizowanie”. Przykładem jest zdanie: „Trzeba zapewnić organizację konferencji” (ZIELENIEWSKI 1979).

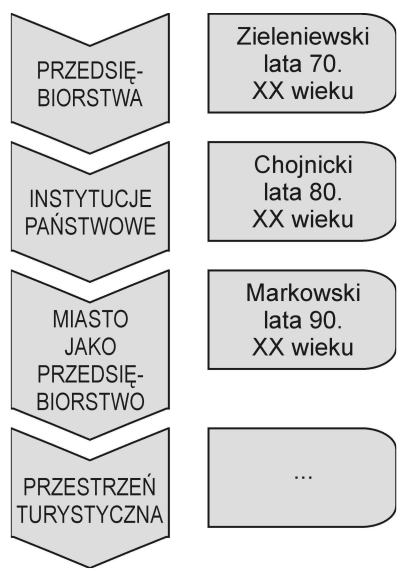

Rys. 1. Zastosowanie pojęcia organizacji

Źródło: opracowanie własne

Przegląd literatury z zakresu organizacji i zarządzania pokazuje, iż początkowo techniki organizacyjne stosowano $\mathrm{w}$ praktyce $\mathrm{w}$ przedsiębiorstwach, z których doświadczeń zaczęły powstawać teorie opracowywane przez naukowców. Następnie stosowano je w instytucjach państwowych, a w latach 90. minionego stulecia zaczęto postrzegać miasto jako przedsiębiorstwo, a co za tym idzie mówić o organizacji przestrzeni miejskiej. Dotychczas brakuje jednak opracowania dotyczącego organizacji przestrzeni turystycznej, którą niniejszy artykuł stara się uzupełnić (rys. 1). 
W literaturze dotyczącej organizacji można odnaleźć bardzo dużo definicji tego pojęcia, o wielu znaczeniach i różnorodnych jego aspektach. Są one ważną inspiracją do rozważań na temat organizacji przestrzeni turystycznej.

\section{Przestrzeń miejska}

Kolejnym pojęciem, które należy rozważyć jest „przestrzeń miejska”. Definiowana jest ona przez S. LISZEWSKIEGO (2012) jako „część (podprzestrzeń, przestrzeń cząstkowa) przestrzeni geograficznej, odznaczająca się specyficzną organizacją i krajobrazem, na której dominuje pozarolnicza działalność człowieka, a obszar ten ma określony formalnie status prawny. Przestrzeń ta zamieszkała jest przez wyróżniającą się wieloma cechami społeczność lokalną. W pewnym stopniu można utożsamiać przestrzeń miejską z przestrzenią zurbanizowaną."

W świetle tej definicji jedną z najważniejszych cech wyróżniających podprzestrzeń miejską z ogólnej przestrzeni geograficznej jest jej organizacja.

Czynniki określające organizację przestrzeni miejskiej wymienia S. LISZEWSKI (2012): prawnowłasnościowe (geodezyjne), morfologiczno-historyczne, funkcjonalne, administracyjno-instytucjonalne i społeczno-kulturowe.

Autor zauważa, że ważnym aspektem badań nad miastem jest sposób zorganizowania przestrzeni miejskiej z punktu widzenia potrzeb mieszkańców, co ma na celu poprawę warunków ich życia (LISZEWSKI 2008). Taki punkt widzenia będzie również istotny dla organizacji przestrzeni turystycznej, ponieważ działania prowadzące do zorganizowania tej przestrzeni również powinny mieć w centrum swojego działania człowieka, w pierwszym swoim działaniu stworzenie dogodnych warunków dla turysty, a w konsekwencji poprawę warunków życia mieszkańców. S. LISZEWSKI (2012) wyróżnia też rodzaje przestrzeni miejskiej z punktu widzenia mieszkańca, do których zalicza:

1) dom (przestrzeń prywatna),

2) dzielnicę (przestrzeń przejściowa),

3) centrum (przestrzeń publiczna),

4) inne publiczne: ulice, parki, place,

5) przestrzeń pracy. 
W literaturze można również odnaleźć stwierdzenie, że organizacja przestrzeni miejskiej jest uwarunkowana, a nawet zdeterminowana ogólnym położeniem geograficznym (JANISZEWSKI 1991) oraz szczegółowymi cechami geokompleksu przyrodniczego, w którym rozwija się miasto (SZPONAR 2003).

Pojęcie zorganizowania przestrzeni pojawia się $\mathrm{w}$ kontekście przestrzeni miejskiej, która została zdefiniowana w następujący sposób: „Przestrzeń miejską można uznać za zorganizowaną, o ile jest ona odpowiednio do potrzeb miasta podzielona (rozparcelowana), zainwestowana (uzbrojona), wykorzystana funkcjonalnie (użytkowana wielofunkcyjnie), a następnie zagospodarowana (zabudowana). Na organizację mają wpływ decydenci, planiści i inwestorzy." (LISZEWSKI 2012).

Ta definicja z punktu widzenia niniejszych rozważań jest istotna, szczególnie fragment dotyczący osób, które mają wpływ na organizację przestrzeni, gdyż można odnaleźć analogiczne grupy wpływające na przestrzeń turystyczną.

W. MAIK (1997) wyróżnia trzy wymiary przestrzeni miejskiej:

1) morfologiczny - układ przestrzenny elementów morfologicznych miasta organizuje wykonywanie funkcji miejskich;

2) demograficzno-społeczny - przestrzenne rozmieszczenie ludności;

3) funkcjonalny - rozmieszczenie i wzajemne oddziaływanie różnych rodzajów działalności miejskiej, rozważając zagadnienie użytkowania terenów i rozmieszczenia użytków miejskich.

Podobny sposób definiowania pojęcia przedstawia D. SZYMAŃSKA (2013): „Na organizację przestrzeni miasta mają wpływ położenie geograficzno-ekonomiczne oraz położenie topograficzne. Elementami organizującymi przestrzeń miasta są drogi, ulice (elementy liniowe), obeliski, pomniki (elementy punktowe), działki, wolne przestrzenie, skwery, place (powierzchniowe) oraz różnego rodzaju budynki (elementy i przestrzenie kubaturowe)."

T. Markowski, zajmujący się marketingiem terytorialnym miast, prezentuje inne spojrzenie na organizację. Rozpatruje on problematykę organizacji przez pryzmat jej celów, struktury, ludzi i procedury. Miasto również charakteryzuje się tymi elementami.

T. MARKOWSKI (1999) podaje proces zarządzania za H. Fayolą, który składa się z następujących faz: 1) planowanie, 2) organizowanie, 3) decydowanie, 4) motywowanie, 5) kontrolowanie. W tym zestawieniu organizowanie to podział pracy, podział uprawnien decyzyjnych, dobranie sposobu koordynacji, zapewnienie zbiorów informacji i sposobu ich obiegu, pozyskanie i podział zasobów ludzkich, rzeczowych i finansowych. 
Zarządzanie może mieć charakter: ogólny (na poziomie całej organizacji), specjalistyczny (sektorowy) lub operacyjny i wykonawczy. W mieście powinno odbywać się zarządzanie ogólne, które skupia się na: zdefiniowaniu polityki gminy, wyznaczeniu celów i zadań strategicznych, wdrożeniu tej polityki, koordynowaniu, kontrolowaniu i ocenie podmiotów realizujących strategię.

Według T. MARKOWSKIEGO (1999): „Zarządzanie miastem obejmuje zarządzanie urzędem miasta (zarządzanie nakierowane «do wewnątrz») oraz zarządzanie miastem jako całością («na zewnątrz)."

Ciekawy wątek podejmuje C. LANDRY (2013), zajmujący się miastami kreatywnymi. Napisał m.in. o zdolności organizacyjnej miasta w kontekście miasta kreatywnego, ale mogą być przydatne dla każdego miasta. Zdolność organizacyjna według C. LANDRY'EGO (2013) to:

- zdolności przywódcze;

- kompetencje techniczne i znajomość nowoczesnych technologii;

- umiejętność określania strategicznych celów i priorytetów;

- patrzenie na rozwój miasta z perspektywy długoterminowej;

- słuchanie i zasięgania rady innych;

- wzbudzanie zaufania i lojalności;

- inspirowanie i zarażanie entuzjazmem innych decydentów;

- gromadzenie wokół siebie zaangażowanego zespołu;

- osiąganie konsensusu w kluczowych kwestiach poprzez wypracowanie wspólnej wizji, budowania wiary w sukces;

- szybkie i sprawne podejmowanie decyzji.

\section{Przestrzeń turystyczna}

Rozważania na temat przestrzeni turystycznej były podejmowane $\mathrm{w}$ wielu publikacjach. Poniżej wymieniono kilka najistotniejszych.

J. WARSZYŃSKA i A. JACKOWSKI (1979) przedstawili jej definicje o charakterze funkcjonalnym: „przestrzeń turystyczna jest to część przestrzeni geograficznej i społeczno-ekonomicznej, w której zachodzą zjawiska turystyczne".

S. LISZEWSKI (1995) definiuje ją następująco: „przestrzeń turystyczna jest funkcjonalnie wyróżniającą się częścią (podprzestrzenią) przestrzeni geograficznej rozumianej w sensie largo, to znaczy jako przestrzeń, na którą składają 
się elementy przyrodnicze powłoki Ziemi (środowisko naturalne), trwałe efekty działalności ludzkiej w tym środowisku (środowisko gospodarcze), a także środowisko człowieka w rozumieniu społecznym." Autor wskazuje tu funkcjonalny aspekt przestrzeni turystycznej oraz zaznacza, że powodem jej powstania są potrzeby wypoczynku oraz przeżyć, których oczekuje współczesny turysta. Wyróżnia także pięć typów przestrzeni turystycznej, które zostały wyznaczone w oparciu o charakter działalności turystycznej oraz stopień przekształceń przestrzeni geograficznej. Są to:

- przestrzeń eksploracji turystycznej,

- przestrzeń penetracji turystycznej,

- przestrzeń asymilacji turystycznej,

- przestrzeń kolonizacji turystycznej,

- przestrzeń urbanizacji turystycznej.

Charakterystykę powyższych typów przestrzeni przedstawia tab. 1.

Tabela 1. Charakterystyka typów przestrzeni turystycznej

\begin{tabular}{|l|c|c|c|c|}
\hline \multirow{2}{*}{$\begin{array}{c}\text { Typ } \\
\text { przestrzeni }\end{array}$} & $\begin{array}{c}\text { natężenie ruchu } \\
\text { turystycznego }\end{array}$ & $\begin{array}{c}\text { zagospoda- } \\
\text { rowanie } \\
\text { turystyczne }\end{array}$ & $\begin{array}{c}\text { główna funkcja } \\
\text { turystyczna }\end{array}$ & $\begin{array}{c}\text { wpływ działalności } \\
\text { turystycznej na śro- } \\
\text { dowisko naturalne }\end{array}$ \\
\cline { 2 - 5 } & minimalne & brak & poznawcza & nieszkodliwa \\
\hline Eksploracji & $\begin{array}{c}\text { zróżnicowane od ma- } \\
\text { łego do masowego }\end{array}$ & niewielkie & $\begin{array}{c}\text { poznawczo- } \\
\text {-wypoczynkowa }\end{array}$ & uciążliwa \\
\hline Asymilacji & średnie & średnie & $\begin{array}{c}\text { wypoczynkowo- } \\
\text {-poznawcza }\end{array}$ & obojętna \\
\hline Kolonizacji & duże & duże & wypoczynkowa & $\begin{array}{c}\text { przekształcająca } \\
\text { (szkodliwa) }\end{array}$ \\
\hline Urbanizacji & średnie & duże & mieszkaniowa & degradująca \\
\hline
\end{tabular}

Źródło: S. LISZEWSKI (1995).

B. WŁODARCZYK (2009) proponuje następującą definicję: „Przestrzeń turystyczna jest tą częścią przestrzeni geograficznej, w której występuje zjawisko ruchu turystycznego. [...] Warunkiem dodatkowym umożliwiającym jej delimitację jest występowanie zagospodarowania turystycznego, którego wielkość i charakter pozwala określić typ przestrzeni turystycznej."

U tego samego autora pojawia się pojęcie „zorganizowanie przestrzeni turystycznej”, w kontekście zależności między różnymi typami przestrzeni a ich zorganizowaniem, jednak samo pojęcie nie jest tu zdefiniowane. Okreś- 
lone zostały typy przestrzeni w zależności od „liczby, charakteru i wzajemnego położenia elementów, położenia atrakcji turystycznych, relacji między atrakcjami turystycznymi." (WŁODARCZYK 2009). Elementami przestrzeni turystycznej dla B. Włodarczyka jest dziedzictwo kulturowe, dziedzictwo przyrodnicze, infrastruktura oraz człowiek.

A. KOWALCZYK (2010) polemizując z wymienioną definicją uważa, że aby przestrzeń turystyczna mogła istnieć, nie wystarczy zaistnienie ruchu turystycznego, lecz konieczna jest obecność walorów i zagospodarowania turystycznego. Rozpatruje on także atrybuty przestrzeni turystycznej, do których zalicza jej położenie, wielkość i spójność oraz zmienność i trwałość.

\section{Organizacja przestrzeni turystycznej w mieście}

Autorka przychyla się do definicji A. KOWALCZYKA (2010), przyjmując za nim, że do istnienia przestrzeni turystycznej niezbędne są walory turystyczne, zagospodarowanie oraz ruch turystyczny.

Do zdefiniowania organizacji przestrzeni turystycznej zostanie zastosowane zarówno czynnościowe, jak i atrybutowe znaczenie organizacji. Dla dalszych rozważań istotne będą zaproponowane kryteria oceny efektywności organizacji, które mają charakter aplikacyjny, ważny dla podejmowanych rozważań.

Powyższe spostrzeżenia prowadzą do zaproponowania definicji organizacji przestrzeni turystycznej.

Na organizację przestrzeni turystycznej składają się dwa etapy: gospodarowanie przestrzenią turystyczną i jej zorganizowanie (rys. 2). Organizacja przestrzeni turystycznej polega na gospodarowaniu tą przestrzenią. Efektem gospodarowania są relacje między elementami (sprawczymi i kreowanymi), a wynikiem tych relacji jest zorganizowanie przestrzeni turystycznej. Gospodarowanie przestrzenią turystyczną polega na celowym porządkowaniu walorów i zagospodarowania w celu uzyskania synergicznej i uporządkowanej, dobrze funkcjonującej całości. Dzieje się to pod wpływem czynników wewnętrznych i uwarunkowań zewnętrznych. Gospodarowanie przestrzenią turystyczną to zestaw czynności podejmowanych przez jednostki samorządu terytorialnego i przedsiębiorców, aby zaspokoić potrzeby turystów (wzbogacenie oferty turystycznej, poprawa ilości i jakości zagospodarowania, promocja walorów) w celu zwiększenia korzyści ekonomicznych dla miasta, a w konsekwencji poprawy warunków życia mieszkańców (rys. 2). 




Rys. 2. Etapy organizacji przestrzeni turystycznej

Źródło: opracowanie własne

Organizacja przestrzeni turystycznej służy turystom, a w konsekwencji mieszkańcom i przyczynia się do rozwoju miasta.

Elementami przestrzeni turystycznej są elementy kształtowane (zastane) oraz elementy sprawcze (działające, kreujące). Elementy kształtowane to: walory turystyczne oraz zagospodarowanie turystyczne.

Według A. KOWALCZYKA (2010), zagospodarowanie jest elementem planowania przestrzennego, które powinno być poprzedzone analizą uwarunkowań. Jednak czasem jest spontaniczne, poza planowaniem i kontrolą. Autor zauważa, że przy planowaniu zagospodarowania należy połączyć preferencje turystów, ochrony środowiska i dziedzictwa oraz potrzeby ludności i instytucji obsługujących ruch turystyczny oraz regulacje prawne.

Elementy sprawcze (działające, kreujące):

1) przedsiębiorcy z branży turystycznej i bazy towarzyszącej, których celem działania jest osiągnięcie zysku (tworzą zagospodarowanie, ofertę, produkty turystyczne);

2) jednostki samorządu terytorialnego oraz organizacje pozarządowe, których celem działania jest przyciągnięcie turystów, co w dalszej kolejności ma poprawić jakość życia mieszkańców, (kreowanie produktów turystycznych, zagospodarowania, informacji turystycznej).

Wśród czynników wewnętrznych należy wymienić:

- położenie geograficzne,

- stan zachowania walorów turystycznych,

- rodzaj i ilość zagospodarowania turystycznego,

- liczba i sposób zrzeszania się przedsiębiorców,

- istnienie mechanizmów współpracy między jednostkami samorządu terytorialnego a przedsiębiorcami,

- pozycja poszczególnych jednostek samorządu terytorialnego i przedsiębiorców. 
Do uwarunkowań zewnętrznych należą:

- prawodawstwo kraju, system podatkowy,

- sytuacja ekonomiczna na poziomie kraju i świata,

- polityka państwa (w tym turystyczna),

- trendy w turystyce światowej.

Każda zmiana, nawet jednego z czynników czy uwarunkowań, może mieć znaczący wpływ na zmiany w organizacji przestrzeni turystycznej. Jako przykład można podać sytuację, kiedy zmienia się prawo dotyczące turystyki. Wtedy zachowania przedsiębiorców czy władz lokalnych mogą ulec zmianie, a także ich działania i relacje, a co za tym idzie zmienia się sposób gospodarowania i organizowania przestrzeni turystycznej. Zatem zmiany czynników czy uwarunkowań mogą stać się impulsem rozwojowym lub hamującym aktywność elementów kreujących przestrzeń turystyczną, powinny więc być ciekawym aspektem badan naukowych. Aktualnym i ważnym czynnikiem, który powinien być brany pod uwagę $\mathrm{w}$ takich analizach są trendy w turystyce światowej.

Rysunek 3 przedstawia relacje, które zachodzą między poszczególnymi elementami przestrzeni turystycznej. Przedstawiono dwa etapy organizacji przestrzeni turystycznej. Pierwszym etapem jest gospodarowanie tą przestrzenią. Dzieje się to $w$ aspekcie funkcjonalnym, a organizacja ma tu znaczenie czynnościowe. Gospodarowanie polega na kreowaniu przestrzeni turystycznej. Pomiędzy organizatorami turystyki zachodzą relacje o różnym charakterze. Prowadzą one do drugiego etapu, czyli do zorganizowania przestrzeni turystycznej. Na rysunku przedstawiono to w postaci drugiej płaszczyzny, która ma charakter przestrzenny, ponieważ można określić kształt zorganizowanej przestrzeni.

Rysunek 3 pokazuje, że relacje, które zachodzą pomiędzy elementami przestrzeni turystycznej wpływają na jej konkretny kształt w aspekcie przestrzennym. Wśród organizatorów turystyki (element sprawczy) należy wymienić samorząd terytorialny, organizacje pozarządowe i przedsiębiorców. Samorząd terytorialny pod postacią władz miasta, regionu, organizacji turystycznych (m.in. ROT) tworzą (lub nie) odpowiedni klimat do rozwoju turystyki, wprowadzają lokalne regulacje prawne dla jej rozwoju, pomagają lub tworzą bariery, uchwalają strategie, budżet, w którym planują środki na rozwój turystyki, jej promocję, sprzyjanie przedsiębiorcom. Rola jednostek samorządu terytorialnego może być bardzo duża, jeśli turystyka w mieście jest priorytetem lub stanowi ważny element marki, strategii czy wizerunku miasta. 

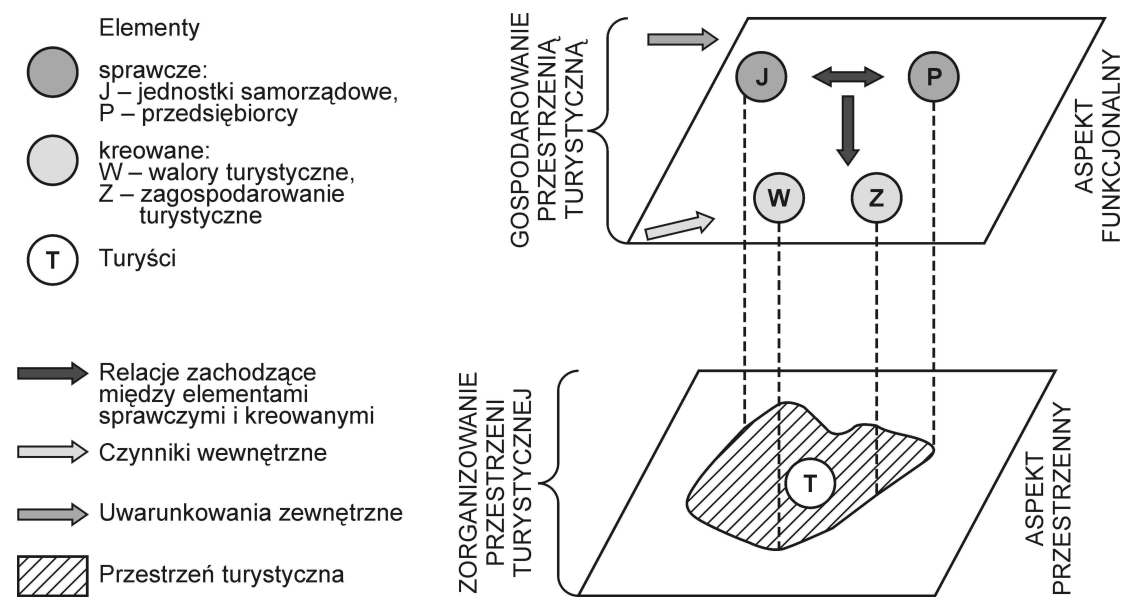

Rys. 3. Organizacja przestrzeni turystycznej

Źródło: opracowanie własne

Drugim istotnym podmiotem są przedsiębiorcy, gestorzy turystyki, do których należy zaliczyć biura podróży, przewodników, hotelarzy, usługi transportowe, właścicieli lub gospodarzy atrakcji turystycznych. Ich znaczenie jest kluczowe, ponieważ ilość i jakość świadczonych przez nich usług ma znaczący wpływ na organizację przestrzeni turystycznej. Mogą oni przyjmować rolę pierwszoplanową (dominującą) i organizować przestrzeń turystyczną, stawiając jednostki samorządu w roli drugoplanowej czy epizodycznej.

Bardzo ważne są relacje, które zachodzą pomiędzy jednostkami samorządu terytorialnego a przedsiębiorcami. Istotne jest to, czy te podmioty ze sobą współpracują i na jakim szczeblu, czy samorząd tworzy odpowiednie warunki do rozwoju przedsiębiorczości w sektorze turystyki, czy nie tworzy barier. Kluczowe jest również to, kto jest głównym czy ważniejszym kreatorem tej przestrzeni. Czy samorząd, który wprowadza regulacje i pomaga sektorowi prywatnemu czy przedsiębiorcy, którzy kreują przestrzeń, a dostają tylko dyskretne wsparcie i brak przeszkód ze strony władz. Kolejnym aspektem jest fakt istnienia mechanizmów i poziomów wspólpracy. Mogą być to relacje na poziomie władz najwyższego szczebla z przedstawicielem stowarzyszenia przedsiębiorców, a może być to tylko współpraca na poziomie konkretnej firmy z urzędnikiem. Istotne jest określenie pozycji głównego organizatora przestrzeni turystycznej: czy jest nim samorząd czy przedsię- 
biorcy, czy jest równowaga między nimi, czy któryś przyjmuje rolę głównego organizatora, dominuje na danym obszarze przejmując inicjatywę.

Turyści są elementem, dla którego podejmowane są działania w sektorze turystyki i jest to grupa, która korzysta $z$ oferty przygotowanej przez samorząd i przedsiębiorców, jednak ma również wpływ na jej kształt, oddziałując m.in. swoimi preferencjami, częstotliwością odwiedzin.

Kluczowym czynnikiem dla organizacji przestrzeni turystycznej są typy relacji i mechanizmy współpracy pomiędzy przedsiębiorcami i władzami miasta.

Wśród czynników wpływających na typy relacji należy wymienić:

- wymianę informacji i doświadczenia pomiędzy przedsiębiorcami i władzami lokalnymi;

- fakt istnienia lidera w obszarze działań turystycznych;

- finansowanie turystyki;

- pozycję turystyki $\mathrm{w}$ polityce miasta (np. istnienie strategii turystycznej);

- ustalenie czy jest zależność władzy lokalnej od turystyki lub odwrotnie;

- określenie czy współpraca jest oparta na wypracowanych, stałych mechanizmach czy jest przypadkowa;

- rodzaj prowadzonych działań przez władze lokalne na rzecz przedsiębiorców działających w obszarze turystyki.

Ostatni punkt wymaga szczegółowego opisania, ponieważ możliwości prowadzonych działań jest niezwykle dużo. W zależności od tego, czy władze miasta korzystają z możliwości wsparcia przedsiębiorców, jaki ich zakres i liczbę stosują, zależy to, jak mocno turystyka w mieście ma szanse zaistnieć, a co za tym idzie te działania przyczyniają się do wzmocnienia relacji, co przekłada się na organizację przestrzeni turystycznej.

Spośród działań podejmowanych przez jednostki samorządu terytorialnego należy wskazać następujące:

1) politykę w zakresie rozwoju przedsiębiorstw turystycznych:

- stworzenie administracyjnych standardów wspierania i działania na rzecz przedsiębiorców;

- podejmowanie uchwał i rozporządzeń określających możliwości działania przedsiębiorców;

- uproszczenie procedur związanych z podejmowaniem i prowadzeniem działalności gospodarczej, np. idea ,jednego okienka"; 
- stworzenie centrum obsługi inwestora, lokalnego okienka przedsiębiorczości;

- stworzenie przez samorząd inkubatorów przedsiębiorczości;

- tworzenie platform wymiany wiedzy biznes-nauka;

- stymulowanie tworzenia nowych firm, np. spin-off, doradztwo, wstępna inkubacja, pakiety usług dla nowych firm;

- stworzenie programu edukacyjno-informacyjnego dla osób planujących działalność gospodarczą w zakresie turystyki;

- możliwość udziału małych i średnich przedsiębiorstw w realizacji zamówień publicznych na dogodnych warunkach, np. podczas realizacji zamówienia podwykonawcami muszą być małe i średnie przedsiębiorstwa działające na danym obszarze, co powinno być uwzględnione w ofertach wykonawców;

- misje gospodarcze;

- organizowanie wizyt studyjnych dla przedsiębiorców.

2) wsparcie finansowe dla przedsiębiorstw:

- przygotowanie terenów pod inwestycje;

- zwolnienie $\mathrm{z}$ podatku od nieruchomości oraz ulgi podatkowe w zamian za stworzenie miejsc pracy;

- możliwość uzyskania korzystnych warunków przy zakupie, dzierżawie oraz użytkowaniu gruntów oraz najmie lokali użytkowych;

- poradnictwo w zakresie lokalizacji inwestycji;

- tworzenie przez samorząd lokalnych funduszy poręczeniowych dla małych i średnich przedsiębiorstw;

- specjalne strefy ekonomiczne;

- pozyskiwanie pieniędzy przez władze lokalne na rzecz rozwoju turystyki (np. fundusze unijne).

3) promowanie wybitnych firm:

- konkursy dla przedsiębiorców, nadania certyfikatów, np. solidna firma, produkt turystyczny roku, hotelarz miesiąca, przedsiębiorca roku;

- informowanie o lokalnych przedsiębiorcach w materiałach promocyjnych miasta.

4) bezpośrednia współpraca władz lokalnych i przedsiębiorców:

- powołanie samorządu gospodarczego (izby, zrzeszenia, stowarzyszenia), opiniowanie przez samorząd gospodarczy aktów prawnych;

- spotkania, konferencje;

- partnerstwo publiczno-prywatne; 
- powołanie forum współpracy władz gminy z lokalnymi przedsiębiorcami;

- tworzenie klastrów;

- rada przedsiębiorców jako ciało doradcze prezydenta miasta;

- zapewnienie udziału przedstawicieli samorządu gospodarczego w tworzeniu planów polityki gospodarczej i zagospodarowania przestrzennego.

$\mathrm{Na}$ podstawie wymienionych rodzajów działań możną podjąć próbę zmierzenia relacji pomiędzy władzami lokalnymi a przedsiębiorcami. Relacje te można zmierzyć m.in.:

1) liczbą rozporządzeń dotyczących turystyki,

2) liczbą ofert współpracy wysuniętych przez samorząd do przedsiębiorców i odwrotnie,

3) faktem, czy istnieje forum gospodarcze, izba przedsiębiorców,

4) tym, czy organizowane są konferencje, spotkania przedsiębiorców z samorządem,

5) liczbą i rodzajem organizowanych konkursów, nadań certyfikatów,

6) ilością i zakresem udogodnień wprowadzonych dla przedsiębiorców,

7) podejmowanymi wspólnymi inicjatywami,

8) wysokością budżetu miasta przeznaczonego na turystykę,

9) liczbą inkubatorów przedsiębiorczości,

10) liczbą podmiotów w klastrze turystycznym.

Na podstawie rodzajów podejmowanych działań, ich liczby oraz charakteru można wyróżnić typy gospodarowania przestrzenią turystyczną (w aspekcie funkcjonalnym). Należą do nich typy:

- administrujący (kontrolny, obojętny, stawiający bariery),

- stymulujący (motywujący, pomocowy),

- partnerski (współpracujący, zaangażowany).

Te typy pojawiają się od momentu świadomego gospodarowania przestrzenią turystyczną, kiedy takie działania nabierają charakteru instytucjonalnego, natomiast wcześniej, jeśli dochodzi do działań w przestrzeni turystycznej, należałoby mówić o działaniach przypadkowych, niezaplanowanych (faza przedinstytucjonalna). Typy gospodarowania przestrzenią schematycznie przedstawia rys. 4, natomiast charakterystykę działań tab. 2.

Typ administracyjny charakteryzuje się jednostronną relacją, która polega na działaniach podejmowanych tylko przez jednostki samorządu terytorialnego na rzecz przedsiębiorców. Są to działania, które mają mały zakres i polegają jedynie na wydawaniu rozporządzeń, regulacji prawnej funkcjo- 
nowania przedsiębiorstw. Turystyka nie zajmuje ważnego miejsca w polityce czy strategii miasta, nie ma specjalnego jej finansowania. Typ administracyjny może przyjmować rożne formy, z jednej strony może mieć charakter obojętny, czyli samorząd nie pomaga przedsiębiorcom, ale jednocześnie nie przeszkadza. Jest to sytuacja, kiedy ten sektor gospodarki nie leży w kręgu zainteresowania władz lokalnych, jednak nie ogranicza go. Druga sytuacja występuje, kiedy zbyt wiele rozporządzeń, ustaw czy kontroli stanowi zagrożenie dla rozwoju przedsiębiorstw, wtedy mamy do czynienia z działaniem narzucającym, stawiającym bariery.

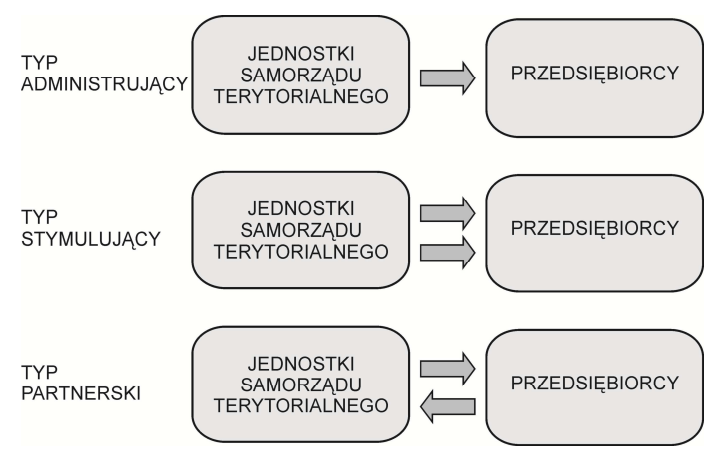

Rys. 4. Typy gospodarowania przestrzenia turystyczną. Źródło: opracowanie własne

Typ stymulujący pojawia się, kiedy samorząd lokalny zauważa potencjalne korzyści dla miasta $\mathrm{w}$ rozwoju turystyki. Wymiana informacji następuje już w dwóch kierunkach. Ze strony władzy lokalnej informacje do przedsiębiorców, a jednocześnie informacja zwrotna o potrzebach, możliwościach pomocy, a także wiedza i doświadczenie na temat praktyki w sektorze turystycznym płynie $\mathrm{z}$ przedsiębiorstw do urzędów. W tym typie relacji można wyróżnić lidera, którym jest samorząd podejmujący działania stymulujące rozwój turystyki. W tym typie relacji są również pieniądze na rozwój turystyki i podejmowanie wielu działań. Strategia miasta lub inny tego typu dokument podkreśla rolę turystyki i jej finansowanie. Istotne są tu działania samorządu w celu aktywizacji przedsiębiorców z sektora turystyki. Wśród nich należy wymienić tworzenie przyjaznego otoczenia dla zakładania i prowadzenia firmy, udogodnienia finansowe, podatkowe, organizacja wizyt studyjnych, nagradzanie wyróżniających się przedsiębiorców i produktów. Ten typ ze względu na swój charakter można inaczej nazwać pomocowym lub motywującym. 
Tabela 3. Typy gospodarowania przestrzenią turystyczną

\begin{tabular}{|c|c|c|c|c|c|}
\hline \multirow[b]{2}{*}{ Typ } & \multicolumn{4}{|c|}{ Cechy } & \multirow[b]{2}{*}{$\begin{array}{c}\text { Rodzaj podejmowanych } \\
\text { działań }\end{array}$} \\
\hline & $\begin{array}{c}\text { wymiana } \\
\text { informacji, } \\
\text { doświad- } \\
\text { czenia }\end{array}$ & lider & $\begin{array}{c}\text { finan- } \\
\text { sowanie } \\
\text { tury- } \\
\text { styki }\end{array}$ & $\begin{array}{c}\text { czy turystyka } \\
\text { jest istotna } \\
\text { w polityce } \\
\text { miasta }\end{array}$ & \\
\hline $\begin{array}{l}\text { Admi- } \\
\text { nistra- } \\
\text { cyjny }\end{array}$ & $\begin{array}{l}\text { jedno- } \\
\text { stronna }\end{array}$ & brak & brak & nie & $\begin{array}{l}\text { - uchwały i rozporządzenia } \\
\text { określające możliwości dzia- } \\
\text { łania przedsiębiorców; } \\
\text { - } \text { kontrola działających przed- } \\
\text { siębiorstw }\end{array}$ \\
\hline $\begin{array}{l}\text { Stymu } \\
\text {-lujący }\end{array}$ & $\begin{array}{l}\text { dwu- } \\
\text { stronna }\end{array}$ & $\begin{array}{l}\text { jednost- } \\
\text { ka samo- } \\
\text { rządu }\end{array}$ & tak & tak & 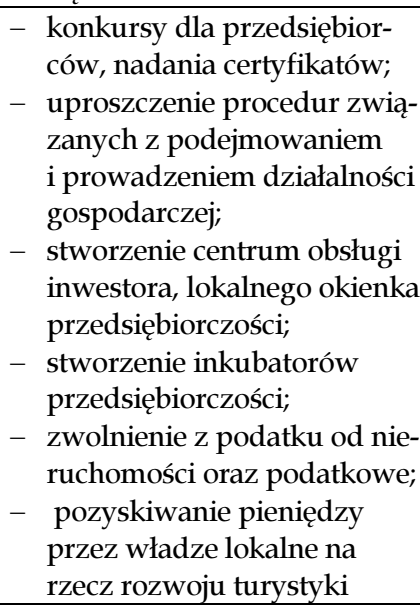 \\
\hline $\begin{array}{l}\text { Part- } \\
\text { nerski }\end{array}$ & $\begin{array}{l}\text { dwu- } \\
\text { stronna }\end{array}$ & $\begin{array}{l}\text { jednost- } \\
\text { ka samo- } \\
\text { rządu } \\
\text { lub } \\
\text { przed- } \\
\text { siębiorca }\end{array}$ & tak & tak & $\begin{array}{l}\text { - powołanie samorządu gos- } \\
\text { podarczego; } \\
\text { - } \text { opiniowanie przez samorząd } \\
\text { gospodarczy aktów praw- } \\
\text { nych; } \\
\text { - } \text { publiczno-prywatne; } \\
\text { - } \text { tworzenie klastrów; } \\
\text { - } \text { rada przedsiębiorców jako } \\
\text { ciało doradcze prezydenta } \\
\text { miasta }\end{array}$ \\
\hline
\end{tabular}

Źródło: opracowanie własne.

Typ partnerski niektóre cechy ma podobne do typu stymulującego, takie jak dwustronna współpraca, finansowanie turystyki oraz ważna jej pozycja $\mathrm{w}$ polityce miejskiej. Różnica jest $\mathrm{w}$ tym, kim jest lider oraz $\mathrm{w}$ rodzaju podejmowanych działań. W tym przypadku liderem może być, tak jak w typie stymulującym, władza lokalna, jednak może nim być również przedsiębiorca lub grono przedsiębiorców. Można tu wyobrazić sobie przykład miasta, 
w którym osoba prywatna buduje park rozrywki, otwiera muzeum czy prowadzi inny typ działalności związanej z turystyką, co staje się impulsem, dzięki któremu miasto zaczyna się rozwijać. Oznacza to, że przedsiębiorca jest liderem, który kreuje ofertę turystyczną i jest głównym aktorem w gospodarowaniu przestrzenią turystyczną. Przykładem prowadzonych działań jest partnerstwo publiczno-prywatne, tworzenie klastrów turystycznych, powoływanie samorządu gospodarczego, którego opinia jest ważna w kreowaniu polityki miejskiej. Ten typ można również określić jako obustronnie zaangażowany, współpracujący.

Częstą sytuacją są typy mieszane. Takim przykładem jest Łódź, gdzie dominuje typ administracyjny, jednak są podejmowane działania z zakresu stymulującego typu gospodarowania przestrzenią.

Należy także zauważyć, że jeśli współpraca w gospodarowaniu tą przestrzenią przebiega chaotycznie, bez lidera czy odpowiedniej kooperacji, może wystąpić problem nadmiaru w ofercie turystycznej. Polega on na braku sprecyzowania tematu oferty, chęci pokazania wszystkiego, co mieści się na danym obszarze, bez próby ograniczenia się do wybranej tematyki. Dobrym przykładem takiego postępowania jest Łódź. Zamiast wybrania 2-3 tematów, w którym miasto mogłoby się "sspecjalizować”, a przez to stworzyć spójny wizerunek turystyczny, oferta obejmuje wszystkie możliwe do uchwycenia w Łodzi tematy. Może warto byłoby ograniczyć propozycje, np. do dziedzictwa przemysłowego, wielokulturowego czy filmowego i stworzyć unikatowy produkt. Natomiast mamy do czynienia z tematami wycieczek czy tras zwiedzania dotyczących Łodzi włókienniczej, fabrykanckiej, żydowskiej, niemieckiej, Tuwima, wielkich łodzian, secesyjnej, filmowej, bajkowej, zielonej, murali, modowej, literackiej. Powstaje nadmiar tematów, w którym łatwo zgubić czy pokazać wyjątkowość miasta.

W procesie gospodarowania przestrzenią turystyczną wywiązują się relacje, dzięki którym można wyróżnić typy gospodarowania wymienione powyżej. Te działania prowadzą do zorganizowania przestrzeni turystycznej. Zatem $\mathrm{w}$ aspekcie przestrzennym mamy do czynienia $\mathrm{z}$ formami zorganizowania przestrzeni turystycznej. Te formy są materialnym efektem organizowania przestrzeni turystycznej, są tym, co możemy odczytać z planu miasta.

Zorganizowana przestrzeń turystyczna może charakteryzować się następującymi cechami:

- uporządkowana,

- konsekwentna,

- chaotyczna,

- zwarta, 
- nasycona,

- nierozwinięta,
- centralna,

- peryferyjna.

Tabela 4. Zależność pomiędzy cechami zorganizowania przestrzeni a typem gospodarowania przestrzenią

\begin{tabular}{|l|l|l|l|l|}
\hline \multirow{2}{*}{$\begin{array}{c}\text { Cechy } \\
\text { zorganizowania } \\
\text { przestrzeni }\end{array}$} & \multicolumn{4}{|c|}{ Typy gospodarowania przestrzenią } \\
\cline { 2 - 5 } & przedinstytucjonalny & administracyjny & stymulujący & partnerski \\
\hline Uporządkowana & & & & \\
\hline Chaotyczna & & & & \\
\hline Konsekwentna & & & & \\
\hline Nasycona & & & & \\
\hline Nierozwinięta & & & & \\
\hline Zwarta & & & & \\
\hline
\end{tabular}

Źródło: opracowanie własne.

W tabeli nie uwzględniono formy centralnej i peryferyjnej, gdyż fakt ich występowania w żaden sposób nie zależy od typu gospodarowania przestrzenią, a przede wszystkim od położenia walorów turystycznych.

Tabela 5. Zależność między typem przestrzeni turystycznej a typem gospodarowania i cechami zorganizowania przestrzeni

\begin{tabular}{|l|l|l|}
\hline $\begin{array}{c}\text { Typ przestrzeni } \\
\text { turystycznej }\end{array}$ & \multicolumn{1}{|c|}{$\begin{array}{c}\text { Typ gospodarowania } \\
\text { przestrzenią turystyczną }\end{array}$} & \multicolumn{1}{c|}{$\begin{array}{c}\text { Cechy zorganizowania przestrzeni } \\
\text { turystycznej }\end{array}$} \\
\hline Eksploracji & przedinstytucjonalny & nierozwinięta, chaotyczna, spontaniczna \\
\hline Penetracji & administracyjny & uporządkowana \\
\hline Asymilacji & stymulujący & uporządkowana, konsekwentna, \\
\hline Kolonizacji & stymulujący, partnerski & uporządkowana, konsekwentna, zwarta \\
\hline Urbanizacji & stymulujący, partnerski & nasycona, zwarta \\
\hline
\end{tabular}

Źródło: opracowanie własne.

\section{Podsumowanie}

Konkretnym efektem zorganizowania przestrzeni turystycznej są korzyści dla różnych grup interesariuszy. Zostały one przedstawione w tab. 6. Liczba i jakość korzyści zależy od efektywności podejmowanych działań w celu zorganizowania przestrzeni turystycznej. Zatem głównym kreatorem tej 
przestrzeni są przedsiębiorcy i władze lokalne, a ich działania przynoszą wymierne korzyści dla dużej liczby interesariuszy.

Tabela 6. Korzyści płynące z organizacji przestrzeni turystycznej

\begin{tabular}{|l|l|}
\hline \multicolumn{1}{|c|}{ Interesariusze } & \multicolumn{1}{c|}{ Korzyści } \\
\hline Przedsiębiorcy & zwiększenie dochodów, zwrot kapitału, satysfakcja z pracy \\
\hline Turyści & poprawa jakości usług, atrakcyjne ceny, atrakcyjność oferty, bezpieczeństwo \\
\hline Mieszkańcy & miejsca pracy, ład przestrzenny \\
\hline Władze lokalne & wpływy z podatków i inwestycji, promocja miasta \\
\hline
\end{tabular}

Źródło: opracowanie własne.

\section{BIBLIOGRAFIA}

BARCZYK S., 2010, Przedsiębiorczy samorząd lokalny i jego instytucje, Wyd. Akademii Ekonomicznej, Katowice.

KOTARBIŃSKI T., 1965, Traktat o dobrej robocie, Zakład Narodowy im. Ossolińskich, Warszawa.

KOWALCZYK A., 2011, "Geograficzne" aspekty przestrzeni turystycznej (nowe spojrzenie na koncepcje przestrzeni turystycznej), [w:] M. Durdywika (red.), Przestrzeń turystyczna, czynniki, różnorodność, zmiany, Uniwersytet Warszawski, Warszawa.

KOWALCZYK A., 2010, Zagospodarowanie turystyczne, PWN, Warszawa.

LANDRY C., 2013, Kreatywne miasto: zestaw narzędzi dla miejskich innowatorów, Narodowe Centrum Kultury, Warszawa.

LISZEWSKI S., 1991, Rola społeczności żydowskiej w organizacji przestrzeni miejskiej, [w:] W. Puś, (red.), Dzieje Żydów w Łodzi 1820-1944: wybrane problemy, Wyd. Uniwersytetu Łódzkiego, Łódź.

LISZEWSKI S., 1995, Przestrzeń turystyczna, „Turyzm”, 5, 2, s. 87-103.

LISZEWSKI S., 2008, Miasto jako przedmiot badan geografii turyzmu w Polsce, „Turyzm”, 18, 1, s. 28-38.

LISZEWSKI S., 2012, Geografia urbanistyczna, PWN, Warszawa.

MAIK W., 2005, Geografia jako nauka o przestrzeni, środowisku i krajobrazie, Łódzkie Towarzystwo Naukowe, Łódź.

MARKOWSKI T., 1999, Zarządzanie rozwojem miast, PWN, Warszawa.

SZPONAR A., 2003, Fizjografia urbanistyczna, PWN, Warszawa.

SZYMAŃSKA D., 2013, Geografia osadnictwa, PWN, Warszawa.

WARSZYŃSKA J., JACKOWSKI A., 1979, Podstawy geografii turyzmu, PWN, Warszawa

WŁodARCzYK B., 2009, Przestrzeń turystyczna: istota, koncepcje, determinanty rozwoju, Wyd. Uniwersytetu Łódzkiego, Łódź.

ZIELENIEWSKI J., 1979, Organizacja i zarzadzanie, PWN, Warszawa.

http:// www.medianet.pl/ multikra/kierunki.htm; 20 lutego 2014 r. 